\title{
Quantitative Trait Loci Associated with Sex Expression in an Inter-subspecific Watermelon Population
}

\author{
Jason Prothro and Hussein Abdel-Haleem \\ Institute of Plant Breeding, Genetics and Genomics, 111 Riverbend Road, University of Georgia, \\ Athens, GA 30602 \\ Eleni Bachlava, Victoria White, and Steven Knapp \\ Monsanto, Woodland, CA 95695 \\ Cecilia McGregor ${ }^{1}$ \\ Department of Horticulture and Institute of Plant Breeding, Genetics and Genomics, University of \\ Georgia, 1111 Miller Plant Sciences, Athens, GA 30602
}

\begin{abstract}
ADDITIONAL INDEX wORDS. andromonoecious, monoecious, hermaphrodite, flower, ACS
Abstract. Sex expression is an important trait in watermelon (Citrullus lanatus), in which monoecious, andromonoecious, and trimonoecious forms are present. The andromonoecious trait is highly undesirable in watermelon breeding programs because it would require emasculation during hybrid development. In contrast to other cucurbits such as melon (Cucumis melo) and cucumber (Cucumis sativus) in which the genes involved in sex expression are well described and have been cloned, only the inheritance of the $a$ gene associated with the andromonoecious trait has been described in watermelon. We used an intersubspecific $C$. lanatus var. lanatus $\times$ C. lanatus var. citroides $\mathrm{F}_{2}$ population to map quantitative trait loci (QTL) associated with percent male (\%M), percent female (\%F), percent hermaphrodite $(\% \mathrm{HM})$, and percent female of pistillate $[\% \mathrm{~F} / \mathrm{P}$ (female + hermaphrodite)] flowers. Four chromosomal regions were identified that were associated with sex expression in watermelon. Major QTL for \%F, $\% \mathrm{HM}$, and \%F/P were colocalized on linkage group $11 \mathrm{~A}$ and explained $31.3 \%$ to $37.7 \%$ of the phenotypic variation observed for the three traits. These QTL are suggested to be the location of the $a$ gene in watermelon. Markers linked to two of the four QTL identified were located within $1 \mathrm{Mb}$ of a 1-aminocyclopropane-1-carboxylic acid synthase (ACS) gene on the watermelon draft genome. ACS genes play a key role in sex expression in melon and cucumber and these genes are therefore candidate genes for further studies to elucidate this trait in another economically important cucurbit crop. The QTL and candidate genes identified in the present study lay the foundation for marker-assisted selection for sex expression traits in watermelon.
\end{abstract}

Watermelon is an economically important member of the Cucurbitaceae family. Sex expression of members of the family is diverse (Grumet and Taft, 2012) and in watermelon, monoecious (separate male and female flowers on the same plant), andromonoecious (separate male and hermaphrodite flowers on the same plant), and trimonoecious (separate male, female, and hermaphrodite flowers on the same plant) forms are found (Ferreira et al., 2002; Maynard, 2001; Robinson and Decker-Walters, 1997; Rosa, 1928). Commercial watermelon cultivars (Citrullus lanatus var. lanatus) express predominantly monoecious flowering types, whereas an andromonoecious flowering habit is common in the wild citron types (C. lanatus var. citroides).

Sex expression is important for watermelon breeders, because the majority of commercially grown cultivars are $F_{1}$ hybrids. Andromonoecious forms are highly undesirable because hermaphroditic flowers require emasculation before cross-pollination. In addition to the andromonoecious trait, the ratio of staminate:pistillate flowers is also of interest to breeders. Commercial watermelon cultivars usually have an

Received for publication 12 Dec. 2012. Accepted for publication 11 Jan. 2013. This research was funded by Monsanto. Patent protection has been sought for the QTL described herein.

${ }^{1}$ Corresponding author. E-mail: cmcgre1@uga.edu. approximate ratio of 7:1 staminate:pistillate flowers (Wehner, 2008 ), but this ratio can vary greatly. For the production of $F_{1}$ hybrids, dioecy (separate male and female plants) are desirable, but this has not been observed in watermelon (Rudich and Zamski, 1985; Salman-Minkov et al., 2008).

A gene $(a)$ controlling the andromonoecious trait in watermelon was described in 1928 by Rosa (1928), but since then, little further research has been conducted to elucidate the trait (Poole and Grimball, 1945; Rudich and Zamski, 1985; SalmanMinkov et al., 2008). In contrast, the inheritance and control of sex expression in melon and cucumber, two other important cucurbits, has been studied in great detail. Briefly, in both melon and cucumber, sex determination is largely controlled by two genes; the $A$ (andromonoecious) and $G$ (gynoecious) genes in melon and the $F$ (female) and $M$ (monoecious) genes in cucumber (Grumet and Taft, 2012; Perl-Treves, 1999). In addition to these genes, modifier genes affecting sex expression have been described in these species and it has been suggested that at least four genes contribute to sex expression (Grumet and Taft, 2012; Kubicki, 1969). In both melon and cucumber, the andromonoecious trait is caused by a mutation in a 1-aminocyclopropane-1-carboxylic acid synthase gene leading to reduced enzyme activity (Boualem et al., 2008, 2009; Li et al., 2009). ACS is a rate-limiting enzyme in the ethylene biosynthesis pathway, and $C m A C S-7$ and $C S A C S 2$ correspond 
to the $A$ and $M$ loci in melon and cucumber, respectively. The $F$ gene in cucumber also codes for an ACS gene (CsACS1G) (Knopf and Trebitsh, 2006; Trebitsh et al., 1997) and together with CsACS 2 causes increased ethylene production, which leads to female flowers (Li et al., 2012).

Four ACS (CitACS1-4) genes have previously been cloned in watermelon (Salman-Minkov et al., 2008). CitACS1 and $C i t A C S 3$ were upregulated by the ethylene precursor 1aminocyclopropane-1-carboxylate and both were expressed in floral tissues. CitACS1 was not differentially expressed in flowers, but CitACS3 was expressed in male and hermaphroditic flowers but not in female flowers (Salman-Minkov et al., 2008). In contrast to melon and cucumber in which ethylene promotes female flowers, in watermelon, ethylene promotes male flower development (Rudich and Zamski, 1985; SalmanMinkov et al., 2008) and thus the role of ACS genes in watermelon sex expression remains to be elucidated.

In the past the lack of high-quality watermelon genetic maps has hampered the ability to find QTL associated with sex expression in this important crop. However, recently watermelon genetic maps that make the mapping of QTL feasible have become available (Ren et al., 2012; Sandlin et al., 2012) and the publication of the draft watermelon genome sequence (Guo et al., 2012) greatly facilitates the identification of candidate genes from QTL. Our aim was to identify QTL associated with sex expression in watermelon and identify candidate genes in these regions for further study.

\section{Materials and Methods}

Plant materials AND genetic map. The development of the C. lanatus var. lanatus $\times$ C. lanatus var. citroides $\mathrm{F}_{2}$ population has been described previously (Sandlin et al., 2012). Briefly, a cross was made between $C$. lanatus var. lanatus ZWRM 50 from China [ZWRM (PI 593359)] and a wild C. lanatus var. citroides accession from South Africa [CTR (PI 244019)]. A single $F_{1}$ plant was self-pollinated to obtain $F_{2}$ seed. One hundred eighty-two $F_{2}$ individuals were genotyped and a genetic map consisting of 338 single nucleotide polymorphism (SNP) markers was constructed (Sandlin et al., 2012).

Trait Phenotyping. $\mathrm{ZWRM} \times \mathrm{CTR} \mathrm{F}_{2}$ plants and parental lines were grown in the greenhouse at the University of Georgia's campus in Athens from May to Aug. 2007 (Prothro et al., 2012). Flower sex expression was recorded as the number of female, male, and hermaphrodite flowers on the first 20 flowering nodes of the main vine on each of $158 \mathrm{~F}_{2}$ plants and parental lines. The sex expression data were converted to percent male, percent female, percent hermaphrodite, and percent female of pistillate (female + hermaphrodite) flowers. Pearson correlations were calculated using JMP 9.0.2 (SAS Institute, Cary, NC).

QTL Detection. Because the sex expression data were percentages, the data were arcsine square root transformed before QTL analysis (Sokal and Rohlf, 1995; Wills et al., 2010). QTL were identified using composite interval mapping [CIM (Model 6 and walk speed of $1 \mathrm{cM}$ ); Zeng, 1993, 1994] using WinQTL Cartographer Version 2.5 (Wang et al., 2011). One thousand permutations were used to determine significance $(\alpha=0.05)$ of the QTL (Churchill and Doerge, 1994; Doerge and Churchill, 1996).

Candidate Genes. We used BLAST search (Altschul et al., 1997) of the draft watermelon genome (Guo et al., 2012) to determine whether watermelon orthologs of the sex expression genes previously identified in melon or cucumber were located close to the QTL regions identified. The following melon and cucumber sequences were used: $F$ locus [CsACS1 (DQ839410) and CsACS1G (DQ839406)] (Knopf and Trebitsh, 2006; Trebitsh et al., 1997), $M$ and $A$ loci [CsACS2 (D89732) and CmACS-7 (EU791280 and EU791279)] (Boualem et al., 2008, 2009), and G locus [CmWIP1 (GQ870274 and GQ870275)] (Martin et al., 2009). The same was done for the CitACS1-4 (EF154455, EF154456, EF154457, and EF154458) genes previously identified in watermelon (Salman-Minkov et al., 2008). The sequences of the SNP markers (Sandlin et al., 2012) closest to the QTL were used to determine the approximate location of the QTL on the draft genome sequence.

\section{Results and Discussion}

ZWRM was monoecious with $75 \%$ male and $25 \%$ female flowers, whereas CTR was andromonoecious with $90 \%$ male and 10\% hermaphrodite flowers (Figs. 1 and 2 ). The $\% \mathrm{M}$ flowers in the $\mathrm{F}_{2}$ population varied from $60 \%$ to $95 \%$ (Fig. $2 \mathrm{~A}$ ). The population included monoecious $(\approx 40 \%)$, andromonoecious $(\approx 30 \%)$, and trimonoecious $(\approx 30 \%)$ plants (Fig. $2 \mathrm{~B}-\mathrm{D})$. The $\% \mathrm{~F} / \mathrm{P}$ trait was calculated in an effort to quantify the trimonoecious trait. The appearance of trimonoecious flowers in watermelon was also reported by Rosa (1928). Sex expression in watermelon seems to have a high degree of plasticity. Similar to the observations of Rosa (1928), hermaphroditic flowers sometimes had only one or two stamens instead of three. Flowers were scored as hermaphroditic if anther(s) were observed in addition to an ovary and stigma.

The $\% \mathrm{~F}$ flowers in the $\mathrm{F}_{2}$ population ranged from $0 \%$ to $30 \%$ (Fig. 2B) and the \%HM flowers from $0 \%$ to $40 \%$. There was a highly significant $(P<0.0001)$ negative correlation between $\% \mathrm{HM}$ and $\% \mathrm{~F}(-0.84)$ (Table 1$)$, indicating that an increase in hermaphroditic flowers is accompanied by a decrease in female flowers. There was a significant positive correlation (0.23) between $\%$ Male and $\% \mathrm{~F} / \mathrm{P}$ and a significant negative correlation $(-0.41)$ between $\% \mathrm{M}$ and $\% \mathrm{HM}$ flowers (Table 1$)$. Thus, the higher the percentage of male flowers, the lower the percentage of hermaphroditic flowers.

Nine QTL associated with sex expression were mapped on four different linkage groups (Table 2; Fig. 3) for the $\% \mathrm{M}, \% \mathrm{~F}$, $\% \mathrm{HM}$, and $\% \mathrm{~F} / \mathrm{P}$ traits. These QTL were colocalized at four regions on LGs $2,7,10$, and $11 \mathrm{~A}$. The percentage phenotypic variation explained ranged from 5.7\% (LG 10) to $37.7 \%$ (LG $11 \mathrm{~A})$ and the LOD-1 support interval for the QTL ranged from $4.4 \mathrm{cM}$ (LG 11A) to $19.4 \mathrm{cM}$ (LG 2). Three QTL for $\% \mathrm{M}, \% \mathrm{~F}$, $\% \mathrm{HM}$, and $\% \mathrm{~F} / \mathrm{P}$ were colocalized on LG $11 \mathrm{~A}$ and explained $8.5 \%, 37.3 \%, 31.3 \%$, and $33.4 \%$ of the phenotypic variation for

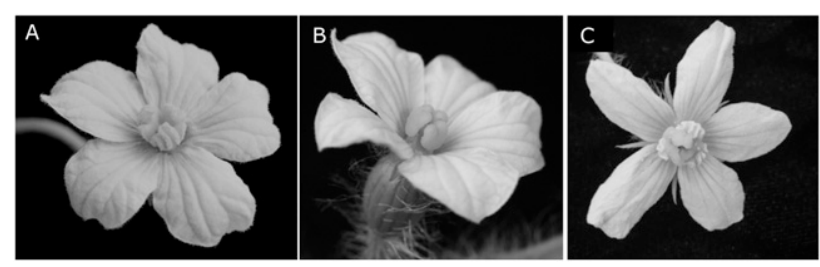

Fig. 1. (A) Male and (B) female flower of Citrullus lanatus var. lanatus [ZWRM (PI 593359)] and (C) an andromonoecious flower from C. lanatus var. citroides [CTR (PI 244019)]. 
(A)
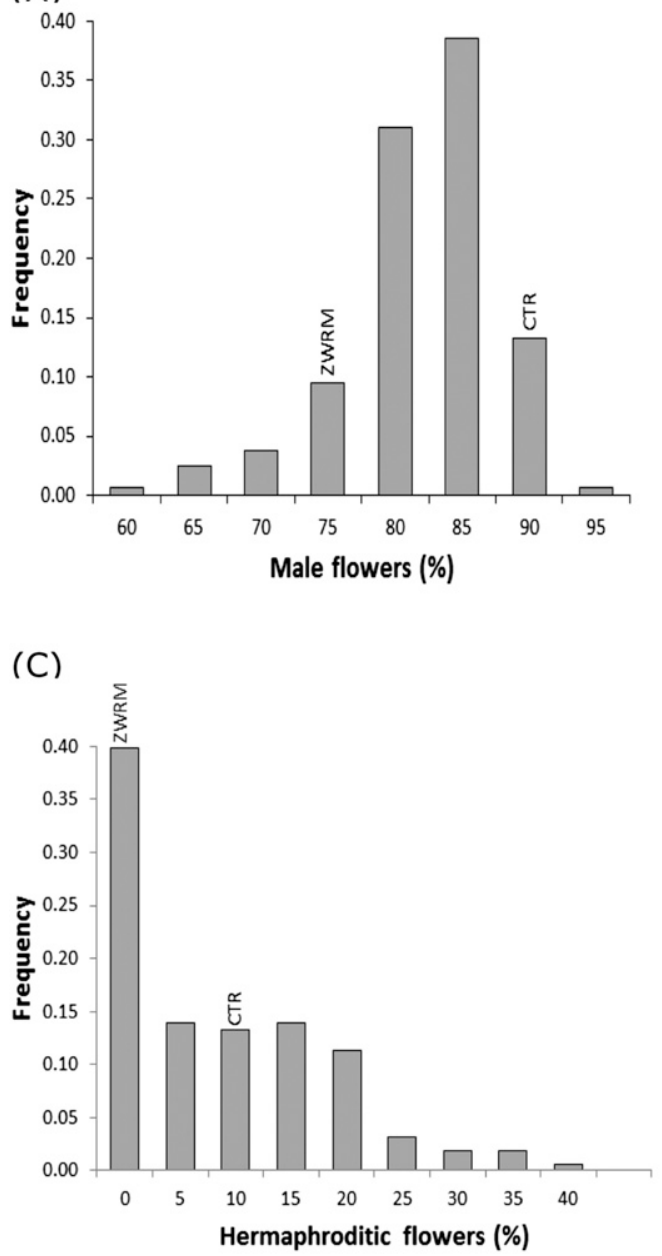

(B)
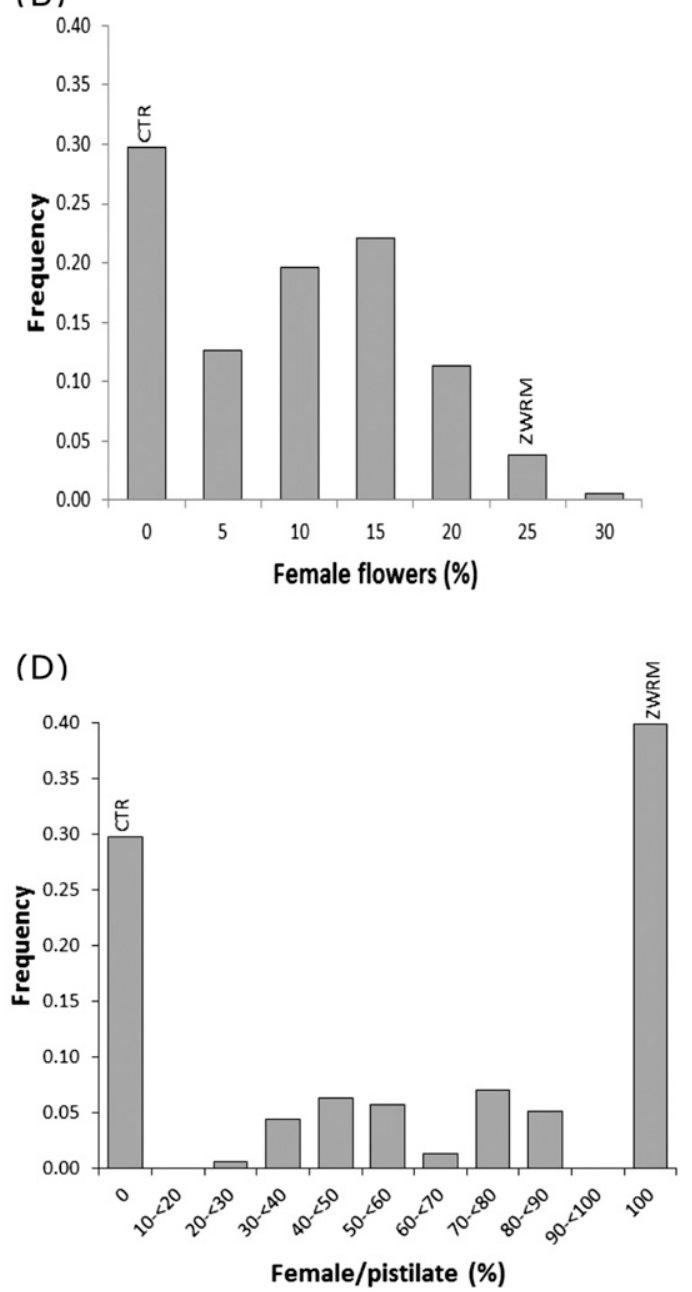

Fig. 2. Frequency distribution of $(\mathbf{A})$ percent male flowers, $(\mathbf{B})$ percent female flowers, $(\mathbf{C})$ percent hermaphroditic flowers, and $(\mathbf{D})$ percent female of pistillate flowers in the first 20 flowers of the main vine of the Citrullus lanatus var. lanatus [ZWRM (PI 593359)] $\times$ C. lanatus var. citroides [CTR (PI 244019)] $F_{2}$ population $(n=158)$. The parental $(Z W R M$ and CTR) phenotypes are indicated.

LG 2

\begin{tabular}{|c|c|}
\hline & $\begin{array}{l}\text { NW0248105 } \\
\text { NW0249396 }\end{array}$ \\
\hline & \\
\hline $6.0^{-}$ & NWO251455 \\
\hline 20.1 & NW0248118 \\
\hline 28.3 & NW0248583 \\
\hline 30.2 & - NW0249314 \\
\hline 38.0 & NW0250837 \\
\hline 42.2 & - NW0248815 \\
\hline 56.5 & NW0250248 \\
\hline 70.6 & NW0248489 \\
\hline 74.4 & NW0249128 \\
\hline 82.8 & NW0248905 \\
\hline & NW0248869 \\
\hline & NW0251470 \\
\hline & NW0251308 \\
\hline $94.0-$ & - NW0248059 \\
\hline $99.8-$ & - NW0252097 \\
\hline 03.6 & NW0250575 \\
\hline 106.4 & NW0251419 \\
\hline & NW0248435 \\
\hline
\end{tabular}

LG 7

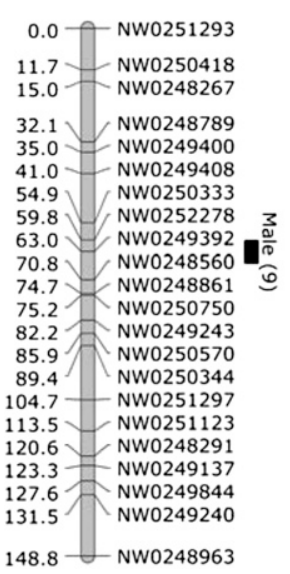

LG 10

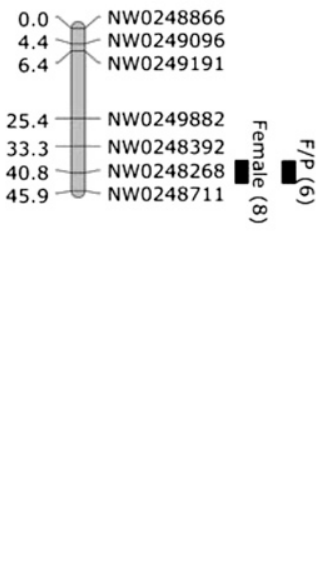

LG 11A

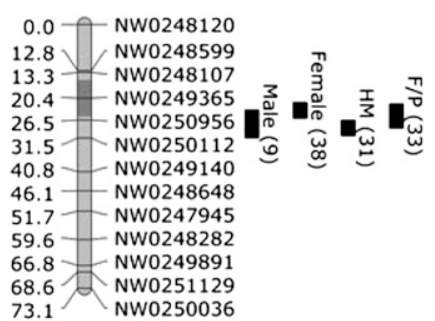

Fig. 3. Quantitative trait loci (QTL) identified for the percent male (Male), percent female (Female), percent hermaphrodite (HM) and percent female of pistillate (F/P) flowers in the first 20 flowers of the main vine of the Citrullus lanatus var. lanatus [ZWRM (PI 593359)] $\times$ C. lanatus var. citroides [CTR (PI 244019)] $\mathrm{F}_{2}$ population $(\mathrm{n}=158)$. The length of the bars is equal to the 1-LOD support interval and the number in parentheses is the percentage of phenotypic variation explained by the QTL $\left(R^{2}\right)$. The shaded area on linkage group (LG) 11A indicates the location of a QTL associated with fruit shape identified previously in the same population (Sandlin et al., 2012). The figure was produced using MapChart Version 2.1 (Voorrips, 2002). 
the traits, respectively. A correlation between fruit shape and pistillate vs. hermaphroditic flowers has been reported in watermelon, cucumber, and melon (Loy, 2006; Poole and Grimball, 1945; Rosa, 1928). In melon, the $a$ gene, together with the $p$ gene (controlling carpel number), affects fruit shape (Abdelmohsin and Pitrat, 2008; Fernandez-Silva et al., 2010; Monforte et al., 2004; Périn et al., 2002). If such a pleiotropic effect is also present in watermelon, one would expect that the $a$ gene would be located in a similar region as QTL controlling fruit shape. Fruit shape data [fruit shape index (FSI)] for the population was available from a previous study (Sandlin et al., $2012)$ and a significant $(P<0.0001)$ correlation $(r=-0.38)$ was observed between FSI and \%HM (data not shown). A major fruit shape QTL has been reported in the ZWRM $\times$ CTR population at $20.4 \mathrm{cM}$ (LOD-1 support interval: 15.4 to $25.5 \mathrm{cM}$ ) from the top of LG $11 \mathrm{~A}$ (Fig. 3) and explained $31.8 \%$ of the phenotypic variation of this trait (Sandlin et al., 2012). This fruit shape QTL overlaps with, or is very close to, the major sex expression QTL identified in the present study (Fig. 3). We postulate that the major QTL on LG $11 \mathrm{~A}$ is the location of the $a$ gene responsible for andromonoecy in watermelon. Fine mapping will be required to determine whether the $a$ gene in watermelon has a pleiotropic effect on fruit shape or whether the correlation is the result of close linkage between two independent genes.

In addition to the colocalized loci on LG $11 \mathrm{~A}$, three other QTL locations associated with sex expression were identified.

Table 1. Pearson correlations for percent male (\%Male), percent female (\%Female), percent hermaphrodite $(\% \mathrm{HM})$, and percent female of total pistillate $(\% \mathrm{~F} / \mathrm{P})$ flowers in the first 20 flowers of the main vine of the Citrullus lanatus var. lanatus [ZWRM (PI 593359)] $\times$ C. lanatus var. citroides [CTR (PI 244019)] $\mathrm{F}_{2}$ population.

\begin{tabular}{lcc}
\hline & \%Male & \%Female \\
\hline$\%$ Female & -0.11 & \\
$\% \mathrm{HM}$ & $-0.41^{* z}$ & $-0.84^{*}$ \\
$\% \mathrm{~F} / \mathrm{P}$ & $0.23^{*}$ & - \\
\hline
\end{tabular}

${ }^{\mathrm{z}}$ Asterisks indicate significant correlations at $P<0.01$.
Two QTL for \%HM and \%F were identified on LG 2 and LG 10 and explained $7.3 \%$ and $7.7 \%$ of phenotypic variation of these traits, respectively. An additional QTL was identified on LG 7 and explained $9.1 \%$ of the phenotypic variation in $\% \mathrm{M}$ flowers. Therefore, it appears that four chromosomal regions are contributing to sex expression in watermelon with each trait $(\% \mathrm{HM}, \% \mathrm{~F}$, or $\% \mathrm{M})$ being controlled by a major gene and a modifying gene.

Three of the identified QTL are located on the same watermelon chromosome as sequence homologs to ACS genes. The marker (NW0250956) linked to the major QTL on LG 11A is located $\approx 0.6 \mathrm{Mb}$ from Cla011230, homologues (E-value: $0.0)$ to $C s A C S 2$ and $C m A C S-7$ (Boualem et al., 2008, 2009) on chromosome 3 of the draft watermelon genome sequence (Guo et al., 2012; Ren et al., 2012). Cla011230 also shows high similarity $(\mathrm{E}$-value $=0.0)$ with the CitACS4 gene previously partially cloned in an individual originating from a cross between $C$. colocynthis and C. lanatus var. lanatus (SalmanMinkov et al., 2008). Salman-Minkov et al. (2008) reported that CitACS4 transcription was not observed in either floral or vegetative tissues and suggested that CitACS4 expression might be below the level of detection with the methodology followed or that the gene was not functional. To elucidate the potential role of Cla011230 in sex expression in watermelon, we are currently in the process of cloning the entire gene in ZWRM and CTR, the parents of the current mapping population as well as other $C$. lanatus accessions and cultivars.

The CsACS1 and CsACS1G genes (Knopf and Trebitsh, 2006; Trebitsh et al., 1997) show homology (E-value $=0.0)$ to the Cla014057 gene on chromosome 1 of the draft sequence of watermelon. However, the marker NW0249392, linked to the QTL, is $\approx 7.7 \mathrm{Mb}$ away from Cla014057 on chromosome 1 . The effect of $C s A C S 1$ and $C s A C S 1 G$ on sex expression in cucumber is the result of a duplication event (Knopf and Trebitsh, 2006) and it remains to be seen whether the gene is duplicated in any watermelon cultivars/accessions. Cla014057 shows homology to CitACS2 (Salman-Minkov et al., 2008) that was isolated from an interspecific cross between $C$. colocynthis and C. lanatus var. lanatus.

Table 2. Genomic regions associated with percent male (\%Male), percent female (\%Female), percent hermaphrodite (\%HM), and percent female of total pistillate $(\% \mathrm{~F} / \mathrm{P})$ flowers in the first 20 flowers of the main vine of the Citrullus lanatus var. lanatus [ZWRM (PI 593359)] $\times$ C. lanatus var. citroides [CTR (PI 244019)] $\mathrm{F}_{2}$ population.

\begin{tabular}{|c|c|c|c|c|c|c|c|c|c|c|}
\hline Trait & $\mathrm{LG}^{\mathrm{z}}$ & $\mathrm{Chr}^{\mathrm{y}}$ & $\begin{array}{l}\text { Closest } \\
\text { marker }^{\mathrm{x}}\end{array}$ & $\begin{array}{l}\text { Position } \\
\text { (cM) }\end{array}$ & $\mathrm{LOD}^{\mathrm{w}}$ & $R^{2}(\%)^{\mathrm{v}}$ & $\begin{array}{l}\text { Additive } \\
\text { effect }^{t}\end{array}$ & $\begin{array}{l}\text { Dominance } \\
\text { effect }^{\mathrm{u}}\end{array}$ & $\begin{array}{l}\text { LOD-1 support } \\
\text { interval (cM) }\end{array}$ & $\begin{array}{l}\text { LOD-1 support } \\
\text { interval }(\mathrm{cM})\end{array}$ \\
\hline$\% \mathrm{HM}$ & 2 & 6 & NW0251455 & 11.0 & 3.71 & 7.3 & 0.082 & -0.013 & 0.6 & 20.0 \\
\hline$\% \mathrm{~F} / \mathrm{P}$ & 2 & 6 & NW0251455 & 9.0 & 3.77 & 6.3 & -0.233 & -0.066 & 0.0 & 18.0 \\
\hline$\%$ Female & 10 & 10 & NW0248268 & 40.8 & 4.76 & 7.7 & 0.077 & -0.008 & 37.3 & 43.8 \\
\hline$\% \mathrm{~F} / \mathrm{P}$ & 10 & 10 & NW0248268 & 40.8 & 3.79 & 5.7 & 0.237 & -0.014 & 37.4 & 43.8 \\
\hline$\%$ Male & $11 \mathrm{~A}$ & 3 & NW0250956 & 26.5 & 3.57 & 8.5 & 0.033 & -0.003 & 23.7 & 31.5 \\
\hline$\% \mathrm{HM}$ & $11 \mathrm{~A}$ & 3 & NW0250956 & 28.5 & 15.88 & 31.3 & -0.165 & -0.061 & 26.5 & 30.9 \\
\hline$\% \mathrm{~F} / \mathrm{P}$ & $11 \mathrm{~A}$ & 3 & NW0250956 & 24.4 & 18.45 & 33.4 & 0.562 & 0.262 & 22.0 & 28.7 \\
\hline
\end{tabular}

${ }^{\mathrm{Z}}$ Linkage group as described in Sandlin et al. (2012)

${ }^{y}$ Chromosome of the draft watermelon genome sequence (Guo et al., 2012; Ren et al., 2012)

${ }^{x}$ Marker sequence information available in Sandlin et al. (2012)

${ }^{\mathrm{w}} \log _{10}$ likelihood ratio.

vPhenotypic variation explained.

uased on arcsine square root transformed data. 
Another ACS homolog (CitACS3) cloned in progeny from the interspecific Citrullus cross by Salman-Minkov et al. (2008) is located on chromosome 6 of the draft genome sequence (Cla006634) and $\approx 0.3 \mathrm{Mb}$ from marker NM0251455 (LG 2). The CitACS3 gene was expressed in male and hermaphroditic buds but not in female buds (Salman-Minkov et al., 2008). The role of ACS genes in sex expression of melon and cucumber makes them prime candidate genes for sex expression studies in watermelon as well as other cucurbit crops (Boualem et al., 2008, 2009; Knopf and Trebitsh, 2006; Li et al., 2009; Trebitsh et al., 1997). The location of the ACS genes close to QTL associated with sex expression in watermelon support this approach, but the role of ethylene in sex expression in watermelon seems to be different from melon and cucumber (where ethylene promotes female flowers). Therefore, although ACS genes are the most obvious candidate genes, we should not exclude the possibility that other genes in the identified QTL regions are involved.

A caveat of the present study is that the plants were grown in the greenhouse on an $F_{2}$ population where a single plant represented a genotype. It is known that environmental conditions as well as other factors (e.g., fruit set) play a role in sex expression in watermelon (Grumet and Taft, 2012; Robinson and Decker-Walters, 1997; Rudich and Peles, 1976), and it remains to be seen whether the QTL reported here will be stable in other populations and environments. However, the colocalization of the major QTL associated with \%HM with a fruit shape QTL in watermelon and a gene with high similarity to the andromonoecious gene identified in other cucurbits give us confidence in the validity of the results reported here.

We have identified QTL associated with sex expression in watermelon including major QTL (LG 11A) that we propose is the location of the $a$ gene responsible for andromonoecy in the species. This research is an important step toward the use of marker-assisted selection as well as the potential cloning of the genes responsible for sex expression in watermelon. Future research will aim to confirm the QTL and candidate genes controlling sex expression in this economically important crop.

\section{Literature Cited}

Abdelmohsin, M.E. and M. Pitrat. 2008. Pleiotropic effect of sex expression on fruit shape in melon, p. 551-556. In: Pitrat, M. (ed.). Cucurbitaceae 2008. Proc. IXth EUCARPIA Meeting on Genetics and Breeding of Cucurbitaceae, Avignon, France, 21-24 May 2008. Altschul, S.F., T.L. Madden, A.A. Schäffer, J. Zhang, Z. Zhang, W. Miller, and D.J. Lipman. 1997. Gapped BLAST and PSI-BLAST: A new generation of protein database search programs. Nucleic Acids Res. 25:3389-3402.

Boualem, A., M. Fergany, R. Fernandez, C. Troadec, A. Martin, H. Morin, M.-A. Sari, F. Collin, J.M. Flowers, M. Pitrat, M.D. Purugganan, C. Dogimont, and A. Bendahmane. 2008. A conserved mutation in an ethylene biosynthesis enzyme leads to andromonoecy in melons. Science 321:836-838.

Boualem, A., C. Troadec, I. Kovalski, M.-A. Sari, R. Perl-Treves, and A. Bendahmane. 2009. A conserved ethylene biosynthesis enzyme leads to andromonoecy in two Cucumis species. PLoS One 4:e6144. Churchill, G.A. and R.W. Doerge. 1994. Empirical threshold values for quantitative trait mapping. Genetics 138:963-971.

Doerge, R.W. and G.A. Churchill. 1996. Permutation tests for multiple loci affecting a quantitative character. Genet. Mol. Biol. 142:285294.

Fernandez-Silva, I., E. Moreno, A. Essafi, M. Fergany, J. Garcia-Mas, A. Martín-Hernandez, J. Álvarez, and A. Monforte. 2010. Shaping melons: Agronomic and genetic characterization of QTLs that modify melon fruit morphology. Theor. Appl. Genet. 121:931940.

Ferreira, M.A.J.F., M.A. de Queiróz, R. Vencovsky, L.T. Braz, M.L.C. Vieira, and R.M.E. Borges. 2002. Sexual expression and mating system in watermelon: Implications for breeding programs. Crop Breeding Appl. Biotechnol. 2:39-48.

Grumet, R. and J. Taft. 2012. Sex expression in cucurbits, p. 353-375. In: Wang, Y.-H., T.K. Behera, and C. Kole (eds.). Genetics, genomics and breeding of cucurbits. Science Publishers, Enfield, $\mathrm{NH}$.

Guo, S., J. Zhang, H. Sun, J. Salse, W.J. Lucas, H. Zhang, Y. Zheng, L. Mao, Y. Ren, Z. Wang, J. Min, X. Guo, F. Murat, B.-K. Ham, Z. Zhang, S. Gao, M. Huang, Y. Xu, S. Zhong, A. Bombarely, L.A. Mueller, H. Zhao, H. He, Y. Zhang, Z. Zhang, S. Huang, T. Tan, E. Pang, K. Lin, Q. Hu, H. Kuang, P. Ni, B. Wang, J. Liu, Q. Kou, W. Hou, X. Zou, J. Jiang, G. Gong, K. Klee, H. Schoof, Y. Huang, X. Hu, S. Dong, D. Liang, J. Wang, K. Wu, Y. Xia, X. Zhao, Z. Zheng, M. Xing, X. Liang, B. Huang, T. Lv, J. Wang, Y. Yin, H. Yi, R. Li, M. Wu, A. Levi, X. Zhang, J.J. Giovannoni, J. Wang, Y. Li, Z. Fei, and Y. Xu. 2012. The draft genome of watermelon (Citrullus lanatus) and resequencing of 20 diverse accessions. Nature Genet. 11 Jan. 2013. <http://www.nature.com/doifinder/10.1038/ng.2470>.

Knopf, R.R. and T. Trebitsh. 2006. The female-specific CsACSIG gene of cucumber: A case of gene duplication and recombination between the non-sex-specific 1-aminocyclopropane-1-carboxylate synthase gene and a branched-chain amino acid transaminase gene. Plant Cell Physiol. 47:1217-1228.

Kubicki, B. 1969. Investigations on sex determination in cucumber (Cucumis sativus L.) VI. Androecium. Genetica Polonica 10:87-99. Li, Z., S. Huang, S. Liu, J. Pan, Z. Zhang, Q. Tao, Q. Shi, Z. Jia, W. Zhang, H. Chen, L. Si, L. Zhu, and R. Cai. 2009. Molecular isolation of the $M$ gene suggests that a conserved-residue conversion induces the formation of bisexual flowers in cucumber plants. Genetics 182:1381-1385.

Li, Z., S. Wang, Q. Tao, J. Pan, L. Si, Z. Gong, and R. Cai. 2012. A putative positive feedback regulation mechanism in CsACS2 expression suggests a modified model for sex determination in cucumber (Cucumis sativus L.). J. Expt. Bot. 63:4475-4484.

Loy, B.J. 2006. Fruit size in melon in monoecious and andromonoecious isolines. Cucurbit Genet. Coop. Rpt. 28-29:12-13.

Martin, A., C. Troadec, A. Boualem, M. Rajab, R. Fernandez, H. Morin, M. Pitrat, C. Dogimont, and A. Bendahmane. 2009. A transposoninduced epigenetic change leads to sex determination in melon. Nature 461:1135-1138.

Maynard, D.N. 2001. An introduction to the watermelon, p. 9-20. In: Maynard, D.N. (ed.). Watermelon characteristics, production and marketing. ASHS Press, Alexandria, VA.

Monforte, A.J., M. Oliver, M.J. Gonzalo, J.M. Alvarez, R. DolcetSanjuan, and P. Arús. 2004. Identification of quantitative trait loci involved in fruit quality traits in melon (Cucumis melo L.). Theor. Appl. Genet. 108:750-758.

Périn, C., L. Hagen, N. Giovinazzo, D. Besombes, C. Dogimont, and M. Pitrat. 2002. Genetic control of fruit shape acts prior to anthesis in melon (Cucumis melo L.). Mol. Genet. Genomics 266:933-941.

Perl-Treves, R. 1999. Male to female conversion along the cucumber shoot: Approaches to studying sex genes and floral development in Cucumis sativus, p. 189-286. In: Ainsworth, C.C. (ed.). Sex determination in plants. BIOS, Oxford, UK.

Poole, C.F. and P.C. Grimball. 1945. Interaction of sex, shape, and weight genes in watermelon. J. Agr. Res. 71:533-552.

Prothro, J., K. Sandlin, H. Abdel-Haleem, E. Bachlava, W. White, S. Knapp, and C. McGregor. 2012. Main and epistatic quantitative trait loci associated with seed size in watermelon. J. Amer. Soc. Hort. Sci. 137:452-457.

Ren, Y., H. Zhao, Q. Kou, J. Jiang, S. Guo, H. Zhang, W. Hou, X. Zou, H. Sun, G. Gong, A. Levi, and Y. Xu. 2012. A high resolution genetic 
map anchoring scaffolds of the sequenced watermelon genome. PLoS ONE 7:e29453.

Robinson, R.W. and D.S. Decker-Walters. 1997. Cucurbits. CAB International Publishing, Wallingford, UK.

Rosa, J.T. 1928. The inheritance of flower types in Cucumis and Citrullus. Hilgardia 3:233-250.

Rudich, J. and A. Peles. 1976. Sex expression in watermelon as affected by photoperiod and temperature. Sci. Hort. 5:339-344.

Rudich, J. and E. Zamski. 1985. Citrullus lanatus, p. 272-274. In: Halevy, A. (ed.). Handbook of flowering. CRC Press, Boca Raton, FL.

Salman-Minkov, A., A. Levi, S. Wolf, and T. Trebitsh. 2008. ACC synthase genes are polymorphic in watermelon (Citrullus spp.) and differentially expressed in flowers and in response to auxin and gibberellin. Plant Cell Physiol. 49:740-750.

Sandlin, K.C., J.M. Prothro, A.F. Heesacker, N. Khalilian, R. Okashah, W. Xiang, E. Bachlava, D. Caldwell, D. Seymour, V. White, E. Chan, G. Tolla, C. White, D. Safran, E. Graham, S.J. Knapp, and C.E. McGregor. 2012. Comparative mapping in watermelon [Citrullus lanatus (Thunb.) Matsum. et Nakai]. Theor. Appl. Genet. 125:16031618.
Sokal, R.R. and F.J. Rohlf. 1995. Biometry: The principles and practice of statistics in biological research. Freeman, New York, NY. Trebitsh, T., J.E. Staub, and S.D. O'Neill. 1997. Identification of a 1-aminocyclopropane-1-carboxylic acid synthase gene linked to the female $(F)$ locus that enhances female sex expression in cucumber. Plant Physiol. 113:987-995.

Voorrips, R.E. 2002. MapChart: Software for the graphical presentation of linkage maps and QTLs. J. Hered. 93:77-78.

Wang, S., C.J. Basten, and Z.B. Zeng. 2011. Windows QTL Cartographer 2.5. Dept. Statistics, North Carolina State Univ., Raleigh, NC. Wehner, T. 2008. Watermelon, p. 381-418. In: Prohens, J. and F. Nuez (eds.). Vegetables I: Asteraceae, Brassicaceae, Chenopodicaceae, and Cucurbitaceae. Springer, New York, NY.

Wills, D.M., H. Abdel-Haleem, S.J. Knapp, and J.M. Burke. 2010. Genetic architecture of novel traits in the Hopi sunflower. J. Hered. 101:727-736.

Zeng, Z.B. 1993. Theoretical basis of separation of multiple linked gene effects on mapping quantitative trait loci. Proc. Natl. Acad. Sci. USA 90:10972-10976.

Zeng, Z.B. 1994. Precision mapping of quantitative trait loci. Genetics 136:1457-1468. 